\title{
Effects of Area Closure on Selected Soil Physico-Chemical Properties in Hidabu Abote District, North Shewa Zone, Oromia
}

\author{
Endale Bedada $^{1, *}$, Feto Esimo ${ }^{2}$, Alemayehu Muluneh ${ }^{3}$ \\ ${ }^{1}$ Fitche Agricultural Research Center, Fitche, Ethiopia \\ ${ }^{2}$ Oromia Agricultural Research Institute, Finfinne, Ethiopia \\ ${ }^{3}$ Biosystem and Environmental Engineering Department, Hawassa University, Hawassa, Ethiopia
}

Email address:

endenat2008@gmail.com (E. Bedada)

*Corresponding author

\section{To cite this article:}

Endale Bedada, Feto Esimo, Alemayehu Muluneh. Effects of Area Closure on Selected Soil Physico-Chemical Properties in Hidabu Abote District, North Shewa Zone, Oromia. Journal of Energy, Environmental \& Chemical Engineering. Vol. 5, No. 1, 2020, pp. 1-9. doi: $10.11648 /$ j.jeece. 20200501.11

Received: March 23, 2020; Accepted: April 9, 2020; Published: April 29, 2020

\begin{abstract}
This study was conducted at sire moresse area closure, Hidabu abote district, North shewa zone, Oromia Regional State to evaluate the effects of area closure on selected physic-chemical properties of soils. In this study area closure sites were compared with adjacent open grazing land in similar landscape positions for soil fertility buildup. Soil samples were collected from the experimental fields using Randomized Complete Block Design (RCBD) with factorial arrangement to evaluate selected soil physico- chemical properties. Data analyses were carried out using analysis of variance appropriate to general linear model (GLM). A total of 36 undisturbed and 36 disturbed soil samples were collected from both closed and open grazing land at 10 and $20 \mathrm{~cm}$ sampling depths along each slope position with three replication. The result of the study indicated that the mean value of most of soil physical and chemical properties were higher at area closure than adjacent open grazing land and also higher at bottom slope position than middle and upper slope position. The mean of Air filled porosity and Bulk density were lower at both area closure management practices and bottom slope position. Bulk density, Total Porosity, volumetric soil moisture content and saturated hydraulic conductivity at $20 \mathrm{~cm}$ sampling depth were shows significantly different with respect to management practices. Similarly, soil chemical properties such as EC, OC, AvP and CEC were shows significantly different with respect to management practices. Soil structure quality, Texture, BD, TP, SMC, EC and TN were shows significantly different under the three slope position. The overall output from the research showed that physical and chemical properties of soil in area closure areas are improving. Area closures act as important sinks of water and reduce soil erosion. From this study it was possible to conclude that area closure improves soil physical and chemical properties.
\end{abstract}

Keywords: Area Closures, Open Grazing Land, Soil Physical Properties, Soil Chemical Properties

\section{Introduction}

Land degradation is a serious global environmental problem. However, wide disparity exists on the extent, depth, type and drivers of the problem [20]. Improper land use, drought, vegetation loss, soil erosion are the principal agents $[29,58]$ and soils play a central role in protection and regulation of land resources.

The problem of soil degradation in Ethiopia is a well- established fact and the apparent soil degradation in the country today can be regarded as a direct result of the past agricultural practices in the high lands. [41] Have also confirmed that anthropogenic effects continue to be the causes and driving factors for soil degradation in Ethiopia. Land use changes, mainly conversion of natural forest to agricultural and grazing lands are known to result in changes in soil chemical, physical and biological properties [25], yet the sign and magnitude of these changes vary with land cover 
and land management [11]. Conversion of natural landscapes into cultivated and grazing systems cause an abrupt decline in soil organic matter and reduces the nutrient content of soil through reduced litter production, increase erosion rates and decomposition of organic matter by oxidation [13]. Unmanaged livestock overgrazing of grass land is one of the most important factors that results in grass land degradation, soil erosion and nutrient losses [55].

Soil degradation is a term that encompasses processes involving the degradation of soil physical, biological and chemical characteristics and/or conditions and soils are a vital natural resource that is not capable of being renewed on the human time scale [30]. It is a living and dynamic natural body that plays many key roles in terrestrial ecosystems, for instance, as sources of available nutrients to plants, maintenances in hydrological stability and biological diversity. Degradation of soil quality is manifested through water and wind erosion, organic matter and nutrient depletion, soil compaction, soil acidity, and decreased microbial activity [9]. Sustaining soil and environmental features are the most effective methods for ensuring sufficient food supply to support life, reduce soil degradation and improve soil health [50].

In Ethiopia, only $25 \%$ of the land rehabilitation targets in terms of reforestation efforts and soil conservation schemes have been accomplished and most of the physical soil conservation measures and community forest plantations were destroyed [4]. To combat these severe resource degradation problems national level environmental conservation and rehabilitation efforts were started by the Government of Ethiopia (GoE), since 1980s, has supported rural land rehabilitation through watershed development approach; and management has moved from a focus on physical SWC to the integration of social, economic, and environmental development [39].

In this regard, the practice of establishing area closures has emerged as a promising practice in different parts of Ethiopia, namely in Tigray [40], and Welo and Shewa [51].

Area closures are areas selected for natural regeneration of the native flora as a means of land reclamation through protection of the areas from human and animal interference [5] and It reduce nutrient loss from a site by controlling runoff (vegetation acting as a physical barrier to soil erosion), this eventually improves the capability of the land to support diverse plant species, including exotic plantations [38]. Since the objective of most area closures is for site rehabilitation, they were usually established in steep, eroded and degraded areas used for grazing and crop production in the past $[5,19]$.

According to the reports from case studies conducted on closure in the central and northern highlands of Ethiopia; area closure had twice the plant species richness and diversity value compared with communal grazing lands after 22 years of closure establishment [52] and an increase in soil organic matter of $1.1 \%$ and total $\mathrm{N}$ of $0.1 \%$ after 10 years of closure establishment $[35,36]$. Also, a considerable decrease in soil loss was reported after the establishment of area closure on communal grazing lands $[15,22,24]$ reported that the soil physical properties (soil texture, soil moisture content, soil bulk density and water holding capacity) are shows significant changes under closure than opened land (control) ones. Area Closures also reduce nutrient loss from a site by controlling runoff (vegetation acting as a physical barrier to soil erosion) [52].

Due to overgrazing, the natural vegetation in the northern highlands of Ethiopia has virtually disappeared, leaving degraded communal grazing lands with irregularly spaced trees and shrubs and vast areas of bare lands devoid of vegetation [6].

Most of the communal lands in North Shewa Zone of Oromia Region, particularly Hidabu Abote District are degraded and unproductive due to the deterioration of the physical, chemical, and biological properties of the soil, mainly due to accelerated rate of soil erosion and poor management practices [43]. Although the restoration ecology and buffering effect of closed areas have been well studied $[2,14]$, there are relatively few studies in the country, which would provide a measure of the effect of area closure as one strategy to help prevent decline of soil fertility and improving soil quality.

Furthermore, there are no enough quantitative studies that analyze the impact of area closure on soil physical and chemical properties in the country, particularly in this study area.

Therefore, this study was initiated in the light of assess the possible effects of area closure compared to adjacent open grazing land on selected soil physical and chemical properties in the study area.

\section{Materials and Methods}

\subsection{Description of the Study Area}

The study area is situated in Oromia Regional State of Ethiopia at North Shewa Zone, Hidabu Abote district. Geographically, it lies between $9^{\circ} 48^{\prime} 30^{\prime \prime} \mathrm{N}$ and $10^{\circ} 4^{\prime} 40^{\prime \prime} \mathrm{N}$ latitude and $38^{\circ} 24^{\prime} 0^{\prime \prime} \mathrm{E}$ and $38^{\circ} 40^{\prime} 12^{\prime \prime} \mathrm{E}$ longitude (figure 1). It is at about $142 \mathrm{~km}$ in north of Addis Ababa, the capital of Ethiopia and $30 \mathrm{~km}$ from Fitche town, the Zonal capital.

Average annual temperature varies from 13 to $23^{\circ} \mathrm{C}$, while the annual rainfall varies between 1500 and $1700 \mathrm{~mm}$. The altitude of the study area ranges from 1160 to $2400 \mathrm{~m}$ above sea level and the district divided into three traditional major agro-climatic zones 'baddaa' agro-climatic zone (high land); 'badda Daree' agro-climatic zone (intermediate elevation); 'Gammojjii' agro-climatic zone (low land) [43]. The area is characterized by undulating, rugged and hilly topography. Mixed agriculture is the major economic activity and Teff, Barley, Haricot Bean, Wheat, Sorghum and Maize are the major crops grown in the district [43]. According to the data obtained from the District Agricultural Office [43], the major land use types in the district include Grazing land shared about $7.5 \%$ while community, state and natural forests and 
bush land $8.1 \%, 12.5 \%$ degraded land and The remaining $71.9 \%$ was Agricultural land and others. The major vegetation types of the study area are characterized by acacia woodland which includes species such as A. abyssinica, A. albida, A. seyal, A. tortilis, etc.), Moreover, other tree species like Balanites aegyptiaca, Combretum molle, Croton macrostachyus, Dodonaea angustifolia, Erythrina abyssinica, Cordia africana, and Eucalyptus species are grown.

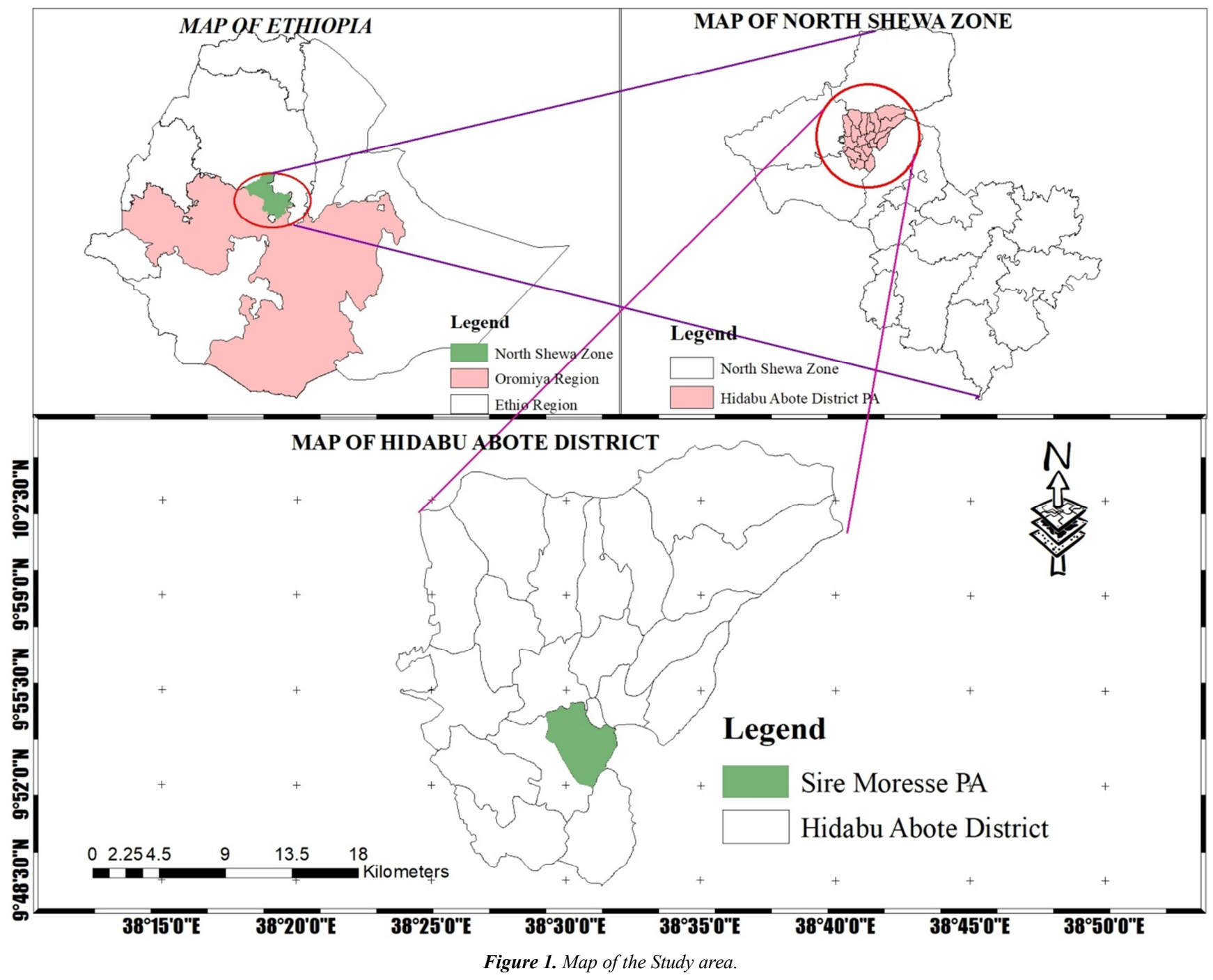

\subsection{Experimental Design and Sampling}

The experiments were laid down in Randomized Complete Block Design (RCBD) with factorial arrangement. The experimental plots containing each land use types (area closure and open grazing land as control) were replicated three times in the selected land use types which were systematically located across the slope position. Altogether (3 replication $\times 3$ slope position $\times 2$ Land use type $\times 2$ sampling depths $=36$ sampling plots) were established.

Soil samples were collected from both land use type (area closure and open grazing land) at three slope position namely upper, middle and bottom slope position with three replication. At each sampling locations, Composite soil samples were collected from $10 \mathrm{~cm}$ and $20 \mathrm{~cm}$ depths from four corners and center of a plot of $10 \mathrm{~m} \times 10 \mathrm{~m}$ size using an " $X$ " sampling design [31] unless soil depth was limited either by stoniness or bedrock. The disturbed samples were collected using auger whereas soil core sampler was used to collect the undisturbed samples. Generally, total of 36 undisturbed and 36 disturbed soil samples were collected from each sampling location and depths.

\subsection{Laboratory Analysis}

Undisturbed soil samples were used for determination of bulk density, soil moisture content, total porosity, air-filled porosity and saturated hydraulic conductivity. Prior the measurement, excess soil was carefully removed by spatula in field to remove excess soil and stored in fridge at $2^{\circ} \mathrm{C}$. The disturbed soil samples were used for the analysis of soil texture and soil chemical properties. Composite soil samples were tagged, mixed well, air dried, ground, sieved with $2 \mathrm{~mm}$ sieve and further sieved to pass through $0.5 \mathrm{~mm}$ size sieve for the analysis of total nitrogen content of the soil and the samples were analyzed following standard procedures at National Soil Testing Laboratory, Addis Ababa, Ethiopia. The cores samplers were covered with nylon cloth from the 
bottom, and saturated step-wise with capillary water from beneath. Then, the samples were used for measurement of saturated hydraulic conductivity (Ksat) using constant head method as described in [28]. The measurements of average value of water discharge (Q) (unit: $\mathrm{mm}^{3} \mathrm{hr}^{-1}$ ) collected after it reached steady state, soil length (L) $[\mathrm{mm}]$, cross-sectional area of the soil sample (A) [unit: $\mathrm{mm}^{2}$ ], and hydraulic head (H) $[\mathrm{mm}]$, were used to determine the Ksat $\left(\mathrm{mm} \mathrm{hr}^{-1}\right)$ using Darcy's equation, which is given by:

$$
K_{\text {sat }}=\frac{Q L}{A t H}
$$

Soil Bulk Density was determined by using the core method by followed procedure as described in [42], which involved weighing oven dried sample (at $105^{\circ} \mathrm{C}$ for 24 hours) and divided the value to the volume of core. Soil moisture content was determined gravimetrically and converted to volumetric basis by multiplying it with bulk density of soil by using core sample method. Total porosity (TP), was determined from bulk density and particle density and Air filled porosity was calculated from total porosity and volumetric water content. The determination of soil particle size proportions were carried out by hydrometer method suggested by [46]. Soil reaction (soil $\mathrm{pH}$ ) was determined by a 1:2.5 soil: water ratio using a $\mathrm{pH}$ meter as described by [54]. Electrical conductivity was determined in water suspension with soil to water ratio $1: 2.5$ by Conductivity meter [45]. The soil organic carbon (SOC) concentration was determined by using Walkley and Black rapid titration method as described in [46]. Soil organic matter (SOM) was determined by multiplying percent organic carbon by 1.724 [26]. Total nitrogen (TN) was determined by the modified Kjeldahl methods as modified by [46]. The available phosphorus (Av. P) content was determined using Olsen extraction method as described by [54]. Samples were digested and titrated against $0.01 \mathrm{~N} \mathrm{HCl}$ and Available potassium (Av.K) was analyzed using flame photometer [12].
The cation exchange capacity (CEC) was determined by using ammonium acetate method [46].

\subsection{Statistical Data Analysis}

Statistical analysis was performed to test the impact of area closure on selected soil physical and chemical properties using analysis of variance (ANOVA) appropriate to general linear model (GLM). LSD (Least Significant Difference) test at $\mathrm{P} \leq 0.05$ was used for mean separation utilizing $\mathrm{R}$ Software program. Regression analysis was used to relate soil physical properties.

\section{Results and Discussion}

\subsection{Impact of Treatments and Slope Position Difference on Selected Soil Physical Properties}

The results shows that there was a slight variation in soil texture mean value at both sampling depths between treatments across all slope position but statistically there was insignificant difference at $\mathrm{p}<0.05$ between treatments (Table 1). In contrast, there was significant difference at $\mathrm{p}<0.05$ across slope position at $10 \mathrm{~cm}$ sampling depth. It is believed that management practices generally do not alter the textural class of a soil on a field scale within short period of time. But management practices have indirect roles in doing so. Pedologic processes such as erosion, deposition, illuviation and weathering which are shaped by management practices can alter the texture of soils [8]. Under conditions of low vegetation cover, as in the open grazing land case, clay fractions are likely to be lost through processes of selective erosion and migration down the soil profile which ultimately increase the proportion of sand and silt contents in surface soils. According to [47], soil erosion and selective removal of soil particles do affect the particle sizes.

Table 1. Effects of Area closure on soil texture.

\begin{tabular}{|c|c|c|c|c|c|c|c|c|}
\hline \multirow{2}{*}{ Soil depth (cm) } & \multirow{2}{*}{\multicolumn{2}{|c|}{ Soil parameter }} & \multicolumn{2}{|c|}{ Treatments } & \multicolumn{3}{|c|}{ Slope position difference } & \multirow{2}{*}{$\begin{array}{l}\text { Treatments * Slope } \\
\text { position difference }\end{array}$} \\
\hline & & & Closed & Open & Bottom & Middle & Upper & \\
\hline \multirow{4}{*}{10} & Texture & & & & & & & \\
\hline & & Sand (\%) & $35.56^{\mathrm{a}}$ & $39.11^{\mathrm{a}}$ & $26^{\mathrm{a}}$ & $40.67^{\mathrm{a}}$ & $45.33^{\mathrm{b}}$ & NS \\
\hline & & Silt (\%) & $29.56^{\mathrm{a}}$ & $30.56^{\mathrm{a}}$ & $30^{\mathrm{a}}$ & $27^{\mathrm{a}}$ & $31.67^{\mathrm{a}}$ & NS \\
\hline & & Clay $(\%)$ & $36.89^{\mathrm{a}}$ & $29.33^{\mathrm{a}}$ & $44^{\mathrm{a}}$ & $32.33^{\mathrm{a}}$ & $23^{\mathrm{b}}$ & NS \\
\hline \multirow{4}{*}{20} & Texture & & & & & & & \\
\hline & & Sand $(\%)$ & $34.89^{\mathrm{a}}$ & $42.44^{\mathrm{a}}$ & $31^{\mathrm{a}}$ & $33.67^{\mathrm{a}}$ & $49.33^{\mathrm{a}}$ & NS \\
\hline & & Silt (\%) & $25.56^{\mathrm{a}}$ & $31.11^{\mathrm{a}}$ & $28.67^{\mathrm{a}}$ & $29.33^{\mathrm{a}}$ & $27^{\mathrm{a}}$ & NS \\
\hline & & Clay (\%) & $39.56^{\mathrm{a}}$ & $26.44^{\mathrm{a}}$ & $40.33^{\mathrm{a}}$ & $35^{\mathrm{a}}$ & $23.67^{\mathrm{a}}$ & NS \\
\hline
\end{tabular}

Means with same letter in each row are not statistically significant at $\mathrm{P}<0.05$, NS=not significant. Comparisons for treatments and slope position difference were done separately. Treatment* slope position difference refers to the interaction between treatment and slope position difference.

Other Physical properties of soils, collected from two treatments at three slope position along with the interaction effect of treatments and slope position difference, are shown in Table 2. 
Table 2. Effects of Area closure on selected soil physical properties.

\begin{tabular}{|c|c|c|c|c|c|c|c|}
\hline \multirow{2}{*}{$\begin{array}{l}\text { Soil depth } \\
\text { (cm) }\end{array}$} & \multirow{2}{*}{ Soil parameter } & \multicolumn{2}{|c|}{ Treatments } & \multicolumn{3}{|c|}{ slope position difference } & \multirow{2}{*}{$\begin{array}{l}\text { Treatments * Slope } \\
\text { position difference }\end{array}$} \\
\hline & & Closed & Open & Bottom & Middle & Upper & \\
\hline \multirow{4}{*}{10} & $\mathrm{BD}\left(\mathrm{g} / \mathrm{cm}^{3}\right)$ & $1.223^{\mathrm{a}}$ & $1.375^{\mathrm{b}}$ & $1.257^{\mathrm{a}}$ & $1.318^{\mathrm{b}}$ & $1.322^{\mathrm{c}}$ & NS \\
\hline & $\Theta_{\mathrm{w}}\left(\mathrm{cm}^{3} / \mathrm{cm}^{3}\right)$ & $0.40^{\mathrm{a}}$ & $0.341^{\mathrm{b}}$ & $0.41^{\mathrm{a}}$ & $0.394^{\mathrm{a}}$ & $0.31^{\mathrm{b}}$ & NS \\
\hline & $\operatorname{AFP}\left(\mathrm{cm}^{3} / \mathrm{cm}^{3}\right)$ & $0.139^{\mathrm{b}}$ & $0.141^{\mathrm{a}}$ & $0.117^{\mathrm{a}}$ & $0.11^{\mathrm{a}}$ & $0.19^{\mathrm{b}}$ & NS \\
\hline & Ksat $(\mathrm{mm} / \mathrm{hr})$ & $58.618^{\mathrm{a}}$ & $47.625^{\mathrm{a}}$ & $54.93^{\mathrm{a}}$ & $53.13^{\mathrm{a}}$ & $51.31^{\mathrm{a}}$ & NS \\
\hline \multirow{4}{*}{20} & $\mathrm{BD}\left(\mathrm{g} / \mathrm{cm}^{3}\right)$ & $1.224^{\mathrm{a}}$ & $1.379^{\mathrm{a}}$ & $1.291^{\mathrm{a}}$ & $1.277^{\mathrm{b}}$ & $1.337^{\mathrm{c}}$ & NS \\
\hline & $\Theta_{\mathrm{w}}\left(\mathrm{cm}^{3} / \mathrm{cm}^{3}\right)$ & $0.412^{\mathrm{a}}$ & $0.337^{\mathrm{b}}$ & $0.40^{\mathrm{a}}$ & $0.395^{\mathrm{b}}$ & $0.32^{\mathrm{a}}$ & NS \\
\hline & $\operatorname{AFP}\left(\mathrm{cm}^{3} / \mathrm{cm}^{3}\right)$ & $0.126^{\mathrm{a}}$ & $0.143^{\mathrm{a}}$ & $0.11^{\mathrm{a}}$ & $0.123^{\mathrm{a}}$ & $0.172^{\mathrm{a}}$ & NS \\
\hline & Ksat (mm/hr) & $55.947^{\mathrm{a}}$ & $48.174^{\mathrm{b}}$ & $55.13^{\mathrm{c}}$ & $54.71^{\mathrm{b}}$ & $46.34^{\mathrm{a}}$ & NS \\
\hline
\end{tabular}

Means with same letter in each row are not statistically significant at $\mathrm{P}<0.05$, NS=not significant. Comparisons for treatments and slope position difference were done separately. Treatment* slope position difference refers to the interaction between treatment and slope position difference.

The result of the study showed that adjacent Open grazing land plots had statistically significant higher mean value of bulk density than area closure plots (Table 2), which can be attributed to trampling effect from the livestock population and direct impact of raindrops on the area. Overgrazing led to the degradation of vegetation, soil compaction, and wind and water erosion. During sampling, soil crusting and sealing in the open lands was observed, which was resulted from lack of vegetation cover which in turn increase bulk density. The result of this study agrees with the finding of [7] who reported that higher soil bulk density under open grazing land than area closure.

Measured bulk density had showed statistically significant difference at $\mathrm{P}<0.05$ levels among slope position difference at both sampling depths. The mean value of bulk density was highest for upper slope position, lowest for bottom slope and with intermediate value at middle slope position (Table 2). This lowest bulk density at the bottom slope position might be resulted from the land slope which resulted in decreases runoff speed and thereby enhanced sedimentation and organic matter development. Better root abundance, vegetation stand, vegetation production and plant residues were observed at bottom slope position of the land compared to its upper slope position. [57] also pointed out that soil bulk density has a direct relation with slope gradient which might be attributed to the corresponding decline in soil organic carbon content with the increase in slope gradient/steepness.

Volumetric moisture content of the soil at sampling showed a statistically significant difference between treated and untreated land and also among slope position at both depths. The larger numerical values of volumetric moisture content were associated with high organic matter content of area closure than values observed in adjacent open grazing land soils. Similar findings were reported previously. For instance, [27] indicated higher soil moisture content through improvements in soil structure in area under area closure than open grazing lands. It is also an established fact that the increasing organic matter increases the water holding capacity of soils [8]. The men values of volumetric moisture content of soil were highest at the bottom slope position with intermediate value at the middle and lowest at the upper slope position for both sampling depths (Table 2).

Air filled porosity was higher in open grazing than area closure land at both sampling depths (Table 2). This might be due to more pore space of soil was filled by water in the soil of area closure. The mean of air filled porosity was highest at upper, intermediate at the middle and lowest at bottom slope position at both sampling depths (Table 2). This lower air filled porosity at bottom slope position of the land explained that high moisture content of deposited soil at the bottom of slope position. In general the observed air filled porosity of this soil was higher than the value assumed as critical value for plant growth by [18], which is $10 \%$.

The mean value of saturated hydraulic conductivity in the closed area was higher than open grazing land at both sampling depths (Table 2). This might be due to high porosity and organic matter content at treated land and also open grazing land soil might be compacted by livestock. [32] have shown that the decrease in soil porosity in the compacted areas, following livestock trampling of soil, was strongly correlated with an increase of soil penetration resistance and a decrease in hydraulic conductivity. Soil compaction changes the ability of soil saturated Hydraulic conductivity and increases penetration resistance [48]. This study also confirmed with the study of [3] who reported that saturated hydraulic conductivity is related to soil structure. The hydraulic conductivity is obviously higher in aggregated soil than tightly packed soil as in the case of open grazing land, which is exposed to animal trampling. Hydraulic conductivity is also depends on the size of conducting pores than total porosity of the soil.

The soil saturated hydraulic conductivity (Ksat) did not show significant variation at $\mathrm{p}<0.05$ in the study area among slope position difference. The mean value of saturated hydraulic conductivity was highest at bottom part of the slope position at both sampling depths (Table 2). This might be due to higher organic matter content at bottom slope position as a result water erosion which removes fertile soil from the upper part of slope position. In this study there was no significant interaction effect between treatments and slope position for all physical soil parameters at both sampling depths (Table 2).

In general, in contrast with the rapid onset of damage, natural recovery of soil structure and post damage regeneration is a slow process that may take years to decades [17]. Though this established fact, area closure, in the study area, enabled the soil to undergone fast recovery from perturbation through natural process. [16] has discussed a 
number of 'natural' processes, which play important roles in restoration of soil structure such as: swelling-shrinkage behavior of soil governed by wetting and drying, root proliferation, and earthworm perturbation. In this study area, natural regeneration process was mainly dominated by root proliferation and earthworm activities. [10] observed that earthworms are important agents for natural restoration of degraded soils.

\subsection{Impact of Treatments and Slope Position Difference on Selected Soil Chemical Properties}

Results of chemical properties of soil under both management systems are shown in Table 3.

Table 3. Effects of Area closure on selected soil chemical properties.

\begin{tabular}{|c|c|c|c|c|c|c|c|}
\hline \multirow{2}{*}{$\begin{array}{l}\text { Soil depth } \\
\text { (cm) }\end{array}$} & \multirow{2}{*}{ Soil parameter } & \multicolumn{2}{|c|}{ Treatments } & \multicolumn{3}{|c|}{ Slope position difference } & \multirow{2}{*}{$\begin{array}{l}\text { Treatments * Slope } \\
\text { position difference }\end{array}$} \\
\hline & & Closed & Open & Bottom & Middle & Upper & \\
\hline \multirow{7}{*}{10} & $\mathrm{PH}$ & $6.25^{\mathrm{a}}$ & $6.033^{\mathrm{a}}$ & $5.98^{\mathrm{a}}$ & $6.28^{\mathrm{a}}$ & $6.167^{\mathrm{a}}$ & NS \\
\hline & $\mathrm{EC}(\mathrm{ds} / \mathrm{m})$ & $0.169^{\mathrm{a}}$ & $0.091^{\mathrm{b}}$ & $0.205^{\mathrm{b}}$ & $0.12^{\mathrm{a}}$ & $0.07^{\mathrm{a}}$ & NS \\
\hline & $\mathrm{TN}(\%)$ & $0.210^{\mathrm{a}}$ & $0.172^{\mathrm{b}}$ & $0.26^{\mathrm{a}}$ & $0.183^{\mathrm{b}}$ & $0.127^{\mathrm{a}}$ & NS \\
\hline & OC (\%) & $2.573^{\mathrm{a}}$ & $2.163^{\mathrm{b}}$ & $3.22^{\mathrm{a}}$ & $2.36^{\mathrm{a}}$ & $1.53^{\mathrm{a}}$ & NS \\
\hline & Av.P (ppm) & $6.25^{\mathrm{a}}$ & $4.68^{\mathrm{b}}$ & $7.79^{\mathrm{a}}$ & $6.04^{\mathrm{b}}$ & $2.57^{\mathrm{b}}$ & NS \\
\hline & Av.K $(\mathrm{mg} / \mathrm{kg})$ & $20^{\mathrm{a}}$ & $11.67^{\mathrm{a}}$ & $30.83^{\mathrm{a}}$ & $12.5^{\mathrm{a}}$ & $4.17^{\mathrm{a}}$ & NS \\
\hline & $\mathrm{CEC}(\mathrm{Cmol} / \mathrm{kg})$ & $27.35^{\mathrm{a}}$ & $27.2^{\mathrm{a}}$ & $32.28^{\mathrm{a}}$ & $27.32^{\mathrm{a}}$ & $22.21^{\mathrm{a}}$ & NS \\
\hline \multirow{7}{*}{20} & $\mathrm{PH}$ & $6.256^{\mathrm{a}}$ & $6.067^{\mathrm{b}}$ & $5.93^{\mathrm{a}}$ & $6.3^{\mathrm{a}}$ & $6.25^{\mathrm{a}}$ & NS \\
\hline & $\mathrm{EC}(\mathrm{ds} / \mathrm{m})$ & $0.138^{\mathrm{a}}$ & $0.073^{\mathrm{a}}$ & $0.18^{\mathrm{a}}$ & $0.08^{\mathrm{b}}$ & $0.06^{\mathrm{b}}$ & NS \\
\hline & TN (\%) & $0.182^{\mathrm{a}}$ & $0.17^{\mathrm{b}}$ & $0.24^{\mathrm{a}}$ & $0.16^{\mathrm{a}}$ & $0.13^{\mathrm{a}}$ & NS \\
\hline & OC (\%) & $1.800^{\mathrm{a}}$ & $1.76^{\mathrm{a}}$ & $2.32^{\mathrm{a}}$ & $1.73^{\mathrm{a}}$ & $1.28^{\mathrm{a}}$ & NS \\
\hline & Av.P (ppm) & $7.452^{\mathrm{a}}$ & $7.29^{\mathrm{b}}$ & $12.93^{\mathrm{a}}$ & $6.85^{\mathrm{a}}$ & $2.33^{\mathrm{a}}$ & NS \\
\hline & Av.K (mg/kg) & $28.33^{\mathrm{a}}$ & $27.22^{\mathrm{a}}$ & $45.00^{\mathrm{a}}$ & $27.50^{\mathrm{a}}$ & $10.83^{\mathrm{b}}$ & NS \\
\hline & $\mathrm{CEC}(\mathrm{Cmol} / \mathrm{kg})$ & $26.94^{\mathrm{a}}$ & $23.36^{\mathrm{a}}$ & $31.83^{\mathrm{a}}$ & $24.72^{\mathrm{a}}$ & $18.90^{\mathrm{a}}$ & NS \\
\hline
\end{tabular}

Means with same letter in each row are not statistically significant at $\mathrm{P}<0.05, \mathrm{NS}=$ not significant. Comparisons for treatments and slope position difference were done separately. Treatment* slope position difference refers to the interaction between treatments and slope position difference.

Soil of the area showed no significant variation $\mathrm{pH}$ mean value between area closure and open grazing land use type. Similarly, the result showed that there was no significant difference in mean $\mathrm{pH}$ values between the soils of the open grazing land and the area closure land at $\mathrm{p}<0.05$ significant level at $10 \mathrm{~cm}$ sampling depths but significantly difference at $20 \mathrm{~cm}$ depths (Table 3 ).

The relatively lower $\mathrm{pH}$ values on the open grazing lands could be associated with loss of basic cations through erosion and leaching as well as low ground cover in the open grazing plots than the area closure ones. According to the classification ranges suggested by [26] $\mathrm{pH}$ values recorded in the soil studied in area closure and adjacent open grazing land were categorized under the slightly acidic reaction.

The mean values of electrical conductivity were statistically significant difference at $\mathrm{p}<0.05$ between open grazing land and the area closures at $10 \mathrm{~cm}$ sampling depth and there was no significant difference at $20 \mathrm{~cm}$ sampling depths (Table 3).

Total nitrogen $(\mathrm{TN})$ contents were statistically significant difference at $\mathrm{p}<0.05$ between area closure and open grazing land at both sampling depths. The area closure land had higher Total nitrogen as compared to open grazing land for both sampling depths (Table 3). The higher total nitrogen content in the area closure is might be the result of higher soil organic matter content and the presence of leguminous plants which have the capacity to fix nitrogen from the atmosphere through the roots' nodules. This finding is in agreement with the finding by [1], who reported that there was significant difference on Total nitrogen between the open grazing land and area closure. [34] Explained that total nitrogen is higher in area closure land use type than open grazing land use type.
Whereas, soils under open grazing land have lower total nitrogen due to continuous overgrazing that results in the removal of grasses and organic matter from the soil.

Organic carbon was relatively significant difference at $\mathrm{p}<0.05$ between area closure and open grazing land at $10 \mathrm{~cm}$ sampling depths but not at $20 \mathrm{~cm}$ sampling depths. The mean value of organic carbon was higher in area closure plots than that of open grazing plots at both sampling depths (Table 3). This could be attributed to the presence of significantly higher organic matter as a result of management practices. The results agrees with the findings of [44] who observed increased organic carbon in the area closure land use type as compared to the open grazing land use type. [21] Showed that the lower content of Soil Organic Carbon under open grassland may be due to reduced organic matter input because of uncontrolled grazing and browsing. [53] mentioned that soil organic carbon values are typically low in the Ethiopian highlands as a consequence of stubble grazing and the absence of fallowing. Area closure land use type has shown an improvement in soil organic carbon against the findings by [37].

The mean value of available Phosphorous for the area closure land was higher than open grazing land and the difference was statistically significant at $\mathrm{P}>0.05$ between area closure and open grazing land plots (Table 3 ). However, in relative terms available phosphorous levels in soils of the closed areas were generally higher than the adjacent open lands, due to the presence of the higher Soil Organic Matter contents of area closure. The result agrees with the study of [23] who reported that the amount of Phosphorus in the surface of untreated plot was lower than the treated land. [49] confirmed that the low levels of available phosphorous 
content might be due to constant removal of soluble phosphorous from root zone by plant roots and eluviations and surface transport through erosion.

The available Potassium values were statistically insignificantly different at $\mathrm{p}<0.05$ between area closures and open grazing land use type at both sampling depths (Table 3 ). The mean values of available potassium values of area closure was higher than open grazing land. This is probably due to the selective removal of this vital macronutrient from open grazing land by accelerated erosion. Because of its high mobility in the soil, potassium is most susceptible to leaching losses [33], which might be the reason for the decline of this vital macronutrient in open grazing land use type. Therefore, probably the higher soil leaching rates in the grazing land caused lower potassium content.

The result of Cation Exchange Capacity shows that there were statistically insignificant difference at $p<0.05$ between the two treatments (open grazing as control and the 16 years closed area) at both sampling depths. The mean value of Cation Exchange Capacity under closed area was higher than the adjacent open grazing land at both sampling depth (Table 3). This finding is in agree with the study by [56] who reported that as cation exchange capacity (CEC) was significantly higher in closed areas than in adjacent open lands. The higher Cation Exchange Capacity in closed areas compared to that of adjacent open land can be due to the presence of difference in organic matter and clay content between the land use types. It is apparent that CEC content positively correlates with organic matter content and soil organic carbon [8].

In general the result of $\mathrm{pH}, \mathrm{OC}, \mathrm{AvP}, \mathrm{AvK}$ and $\mathrm{CEC}$ shows that there were statistically insignificant difference at $\mathrm{p}<0.05$ among slope position difference in $10 \mathrm{~cm}$ sampling depth where as the result of EC and $\mathrm{TN}$ shows that there were significant difference among slope position difference at 10 cm sampling depth and also The result of EC and AvK shows that there were significant difference among slope position difference in $20 \mathrm{~cm}$ sampling depths but the result of $\mathrm{pH}, \mathrm{TN}$, $\mathrm{OC}, \mathrm{AvP}$ and CEC shows there were statistically insignificant difference at $\mathrm{p}<0.05$ among slope position difference in 20 cm sampling depths (Table 3 ). In all cases, the mean values were highest at bottom slope position difference except for $\mathrm{pH}$ at both sampling depths (Table 3). This might be due to the washing away of the fertile soil from the upper part of the land settling at bottom part of the land. As the land slope decreases runoff speed also decreases, sediments and organic matter then start to accumulate.

The interaction of Treatments and slope position difference effects on chemical properties in this study shows there was insignificant interaction between treatments and slope position difference for all chemical properties at both sampling depths (Table 3).

\subsection{Relationship Between Soils Physical Properties}

Bulk density is one of the common parameters used to quantify these changes. This is because of the way of measurement of bulk density. They also used the changes in bulk density to quantify relationships between bulk density and saturated hydraulic conductivity. In this study, strong and significant relationship between bulk density and saturated hydraulic conductivity was obtained (figure 2 ).

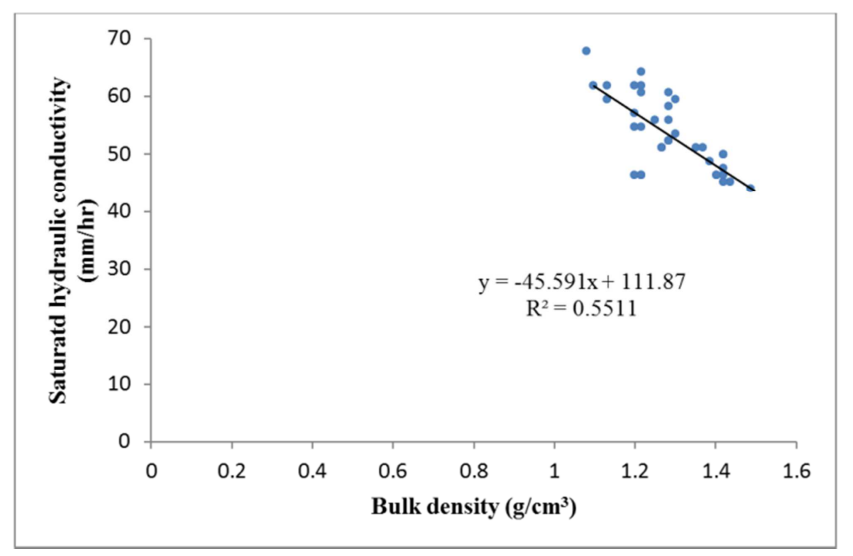

Figure 2. Relationship between Saturated hydraulic conductivity and Bulk density.

The figure shows that there was significant correlation (Ksat=-45.59 BD+111.8, $\mathrm{p}<0.05, \mathrm{R}^{2}=0.551$ ) between saturated hydraulic conductivity and bulk density of soil. The result shows that saturated hydraulic conductivity decreases with increasing bulk density as a response of the smaller volume porosity and organic matter content of soil. Remarkably, the regression equation in this investigation was almost identical to the relationship found by [18] for soils that were collected from different sites of agricultural fields from 10 to 20 depths.

\section{Conclusion and Recommendations}

The results of this study showed that area closures are effective in restoring the nutrient status and quality of degraded soils. The results of the soil analysis showed that most of the soil physical and chemical properties had significant variations with respect to management practices and slope position difference. The study also revealed that area closure farm plots had higher mean value of soil physical and chemical properties other than bulk density and air filled porosity. This may be due to the less biomass return to the open grazing land because major part of above ground biomass was removed by livestock grazing which in turn negatively affect the availability of many soil nutrients. Besides the trampling and compaction effect on the soil due to open livestock grazing and soil erosion problem have a role to play in physical soil degradation of the open grazing land use type. The result of most of physical and chemical properties of soil shows that there were statistically significant differences among slope position. In all cases, the mean values were highest at bottom slope position except for Bulk density, Air filled porosity and $\mathrm{pH}$ at both sampling depths. This might be due to the washing away of the fertile soil from the upper part of the land settling at bottom part of the land.

Based on the improved soil conditions of area closure land, it is possible to conclude that the establishment of area closures 
in the degraded lands is a viable option for soil quality improvement and biodiversity conservation. Therefore from technical point of view, open grazing areas in hilly lands should be changed to area closure before soil physical properties and soil nutrient contents are depleted more and also the management activity carried out in area closure should be strengthened in the future to increase soil fertility improvement

\section{References}

[1] Abiy Tsetargachew, 2008. Area closure as a strategy for land management: a case study at Kelala Dalacha enclosure in the central rift valley of Ethiopia: MSc. thesis, Addis Ababa University, Addis Ababa.

[2] Aerts, R., Mitiku Haile, Muys, B., Deckers, J., Hermy, M. and Moeyersons, J., 2001. Forest rehabilitation and water conservation in the Tigray highlands, northern Ethiopia. European tropical forestry research network, 33: 29-31.

[3] AHuja, L. R., J. W. Naney, and D. R. Nielsen. 1984. Scaling soil water properties and infiltration modeling. Soil Sci. Soc. Am. J. 48: 970-973.

[4] Azene Bekele. 1997. A participatory agro-forestry approach for soil and water conservation in Ethiopia. PhD Dissertation, Wageningen Agricultural University, the Netherlands. 229p.

[5] Bendz, M., 1986. Hill side closures in Welo: Ethiopian red cross society mission report. Vaxjo, Sweden.

[6] Betru Nedessa, Jawad Ali and Nyborg I., 2005. Exploring ecological and socio- economic issues for the improvement of area enclosure management: a case study from Ethiopia. DCG report, 38: 3-30.

[7] Bewket W, Stroosnijder L (2003) Effects of agro ecological land use succession on soil properties in the Chemoga watershed, Blue Nile basin, Ethiopia. Geoderma 111: 85-98.

[8] Brady, N. C. and R. Weil, 2002. The nature and properties of soils. 13 thedition. Pearson Education, Inc., New Jersey, 960p.

[9] Bezdicek, D. F., Beaver, T., Granatstein, D. (2003). Subsoil ridge tillage and lime effects on soil microbial activity, soil $\mathrm{pH}$, erosion, and wheat and pea yield in the Pacific Northwest, USA, Soil \& Tillage Research, 74, 55-63.

[10] Capowiez Y, Dittbrenner N, Rault M, Triebskorn R, Hedde M, Mazzia C (2010) Earthworm cast production as a new behavioural biomarker for toxicity testing. Environ Pollut 158: 388-393.

[11] Celik I (2005) Land use effects on organic matter and physical properties of soil in a southern Mediterranean highland of Turkey. Soil Tillage Res 83: 270-277.

[12] Chapman, H. D. (1965). Cation exchange capacity. In: Black, C. A., Ensminger, L. E. and Clark, F. E (ed). methods of soil analysis. agronomy. agro., inc., Madison, Wisconsin. 9: 891- 901.

[13] Chen C, Xu Z (2010) Forest ecosystem responses to environmental changes: the key regulatory role of biogeochemical cycling. J Soil Sediment 10: 210-214.

[14] Descheemaeker, K., Nyssen, J., Rossi, J., Poesen, J., Mitiku Haile, Raes, D., Muys, B., Moeyersons, J., Deckers, J., 2005. Sediment deposition and pedogenesis in exclosures in the Tigray highlands, Ethiopia. Geoderma, 32: 291-314.
[15] Descheemaeker, K. (2006). Pedological and hydrological effects of vegetation restoration in exclosures established on degraded hillslopes in the highlands of Northern Ethiopia. $\mathrm{PhD}$ thesis. K. U. Leuven. 350p.

[16] Dexter, A. R. 1991. Physical soil mechanical properties as influenced by exchangeable catios, 43, 41-63.

[17] Drewry, J. J. 2006. Natural recovery of soil physical properties from treading damage of pastoral soils in New Zealand and Australia: a review. Agriculture, Ecosystems and Environment 114: 159-169.

[18] Dulo H., Feto E., Fisiha G., 2017. Effects of soil bund on soil physical and chemical properties in Arsi Negelle woreda, Ethiopia. Vol-11, pp. 509-516.

[19] Emiru Birhane, 2002. Actual and potential contributions of enclosures to enhance biodiversity in drylands of eastern tigray, with particular emphasis on woody plants.

[20] FAO (2004). Methodological framework for land degradation assessment in dry-lands.

[21] G. Girmay, B. R. Singh, H. Mitiku, T. Borresen, and R. Lal, "Carbon stocks in Ethiopian soils in relation to land use and soil management," Land Degradation and Development, vol. 19, no. 4, pp. 351-367, 2008.

[22] Girmay, G., B. R. Singh, J. Nyssen and T. Borrosen, 2009. Runoff and sediment-associated nutrient losses under different land uses in Tigray, Northern Ethiopia. J. Hydrol., 376: 70-80.

[23] Hadda, M. S. and Sur, H. S. 1987. Effect of land modifying measures on erosion, nutrient, water storage and yield of pearl millet fodder. J. Indian Soc. 35: 480-486.

[24] Hailu, T., L. Negash and M. Olsson, (2001). Millettiaferruginea from South Ethiopia: Impact on Soil fertility and Growth of Maize. Ethiop. J. Agro-forestry system, 46: 9-15.

[25] Houghton RA, Hacker JI, Lawrence KT (2000) The U.S carbon budget: contributions from land use change. Soil Sci 285: 574-578.

[26] Jones, J. B., 2003. Agronomic Handbook: Management of Crops, Soils, and Their Fertility. CRC Press LLC, Boca Raton, Florida, USA, 482p.

[27] Kevin ZM, Nashon KRM, Dickson MN, Moses MN, Wellington NE, William MM, Agnes WMO (2011) Different land use types in the semi-arid rangelands of Kenya influence soil properties. University of Nairobi, Uganda. J Soil Sci Environ Manag 2 (11): 370-374.

[28] Klute, A. and Dirksen, C. 1986. Hydraulic Conductivity and Diffusivity. Part 1. In: "Methods of Soil Analysis", (Ed.): Klute, A. 2 nd Edition, Agronomy Monograph, Vol. 9., American Society of Agronomy, Madison, WI, PP. 687-734.

[29] Lal, R. 2004. Carbon sequestration in dryland ecosystems. Environmental Management, 33, 528-544.

[30] Liu X, Herbert SJ, Hashemi AM, Zhang X, Ding G (2006) Effects of agricultural management on soil organic matter and carbon transformation. Soil Environ 53: 531-543.

[31] Margesin, R., Schinner, F. Manual of Soil AnalysisMonitoring and Assessing Soil Bioremediation. SpringerVerlag Berlin Heidelberg, Innsbruck, Austria, 2005. Department, Finfinne, p 75. 
[32] Marsili, A (1998). Changes of some physical properties of a clay soil following the passage of rubber and metal tracked tractors. Soil Till. Res. 49, 185-199.

[33] Mekuria Argaw (2005). Forest conversion, soil degradation, farmers perception nexus: Implications for sustainable land use in the southwest of Ethiopia. PhD thesis. Cuvillier Verlag G’ttingen. 169p.

[34] Mekuria W, Veldkamp E (2005) Impacts of land use changes on soil nutrients and erosion in Tigray, proceeding on International Agricultural Research fo Development, Ethiopia, pp 11-13.

[35] Mekuria Wolde, 2011. "Exclosure land management for restoration of the soils in degraded communal grazing lands in northern highlands of Ethiopia," Land Degradation and Development.

[36] Mekuria Wolde, 2013. "Conversion of communal grazing lands into exclosures restored soil properties in the semi-arid lowlands of Northern Ethiopia," Arid Land Research and Management, vol., 27, pp. 153-166.

[37] Mekuria W, Langan S, Noble A, Johnston R (2014) Soil Organic Carbon and Nutrient Contents are not influenced by Exclosures established in com- munal grazing land in Nile basin, Northern Ethiopia. International Confer- ence on Advances in Agricultural, Biological \& Environmental Sciences (AABES-2014) Oct 15-16, 2014 Dubai (UAE).

[38] Mengistu, T., Teketay, D., Hulten, H., Yemshaw, Y., 2005. The role of enclosures in the recovery of woody vegetation in degraded dryland hillsides of central and northern Ethiopia. J. Arid Environ. 60, 265-280.

[39] MoARD (Ministry of Agriculture and Rural Development) (2005) Guide line for integrated watershed management. MoARD, Addis Ababa.

[40] Mitiku Haile, Kindeya Gebrehiwot, 2001. Local initiatives for planning sustainable natural resources management in Tigray, northern Ethiopia. Ethiopian journal of natural resources, 3: 303-326.

[41] Nyssen J., J. Poesen, J. Moeyerson, M. Haile, and J. Deckers, 2008. "Dynamics of soil erosion rates and controlling factors in the Northern Ethiopian highlands-towards a sediment budget". Earth Surface Processes and Landforms, vol. 33: 695-711.

[42] Okalebo, J. R., Gathua, K. W., \& Woomer, P. L. (2002). Laboratory methods of plant and soil analysis: a working manual. Tropical Soil Biology and Fertility Programme, Nairobi.

[43] OPEDB (2000) Physical and socio-economic profiles of 180 districts of Oromia Physical Planning.

[44] Quraishi S., Alam, S. M and Sinha, 1977. Study of the Effect of different soil conservation measures in the up land of chotanagpur on physic-chemical properties of soil, J. Soil and Water Conservation Ind. Vol, 27 Nos, 124: pp. 33-36.

[45] Rhoades JD (1996). Electrical conductivity and total dissolved solids. In: Sparks D. L. (ed.): Methods of Soil Analysis. Chemical methods. Soil Sci. Soc. Am. Madison, pp. 417-437.

[46] Sakar, \& Haldar (2005). Physical and chemical method in soil analysis: Fundamental concepts of analytical chemistry and instrumental techniques. New Delhi: New Age International (P) Ltd. Publisher.

[47] Sandor JA, Gersper PL, Hawley JW (1986) Soils at prehistoric agricultural ter- racing sites: site placement soil morphology and classification, in New Mexico. Soil Sci Soc Am J 50: 166-173.

[48] Shafiq, M., Hassan, A., Ahmad, S., 1994. Soil physical properties as influenced by induced compaction under laboratory and field conditions. Soil Till. Res, 29, 13-22.

[49] Smeek, N. E. 2003. P hosphorus: An indicator of pedogenic weathering P. 199-206. In: Berhane F iseha and sahlemedihn Sertsu (Eds.) Assessment of the different phosphorus forms in some Agricultural soils of Ethiopia. Ethiopia Journal Natural Resources. 5 (2): 193-213.

[50] Soares JLN, Espindola CR, Pereira WLM (2005) Physical properties of soils under soil acidity effects on nutrient use efficiency in exotic maize genotypes. J Plant Soil Sci 192: 9-13.

[51] Tefera Mengistu, 2001. The role of enclosures in the recovery of woody vegetation in degraded dry land hillsides of central and northern Ethiopia. MSc. thesis, Swedish university of Agricultural sciences with WGCF in Ethiopia Swedish.

[52] Tefera, M., T. Demel, H. Hulten and Y. Yemshaw, 2005. The role of communities in closed area management in Ethiopia. Mount. Res. Dev., 25: 44-50.

[53] Vancampenhout, k,. Nyssen, J., Desta, G., Deckers, J., Poesen, J., Mitiku, H. and Moeyersons, J. 2005. S tone bunds for soil conservation in the northern Ethiopian highlands: Impacts on soil fertility and crop yield. Soil and T illage Research, 90, 1-15.

[54] Van Reeuwijk L (2002) Procedures for soil analysis, 6th edn, Technical paper 9. Wageningen, the Netherlands.

[55] Wei L, Ha-Zhou H, Zhi- Nan Z, Gao-Lin W (2011) Effects of grazing on the soil properties and $\mathrm{C}$ and $\mathrm{N}$ storage in relation to biomass allocation in an alpine meadow. J Soil Sci Plant Nutr 11 (4): 27-39.

[56] Wolde Mekuriaand, Edzo V., 2005. Impacts of Land Use Changes on Soil Nutrients and Erosion in Tigray, Ethiopia. Proceedings on International Agricultural Research for Development. October 11-13, 2005, Stuttgart-Hohenheim.

[57] Worku Hailu, Awdenegest Moges, Fantaw Yimer, 2012. The Effects of 'Fanya juu' Soil Conservation Structure on Selected Soil Physical \& Chemical Properties: the Case of Goromti Watershed, Western Ethiopia Resources and Environment 2 (4): 132-140.

[58] Zhang, S., Fan, W., Li, Y., Yi, Y. (2017). The influence of changes in land use and landscape patterns on soil erosion in a watershed. Science of the Total Environment, 574, 34-45. 